\title{
TOWARDS THE OPTIMUM SPINAL FUSION DEVICE
}

\section{ISKANJU OPTIMALNEGA UMETNEGA MEDVRETENČNEGA VSADKA}

\author{
Matevž Gorenšek ${ }^{1}$, Monika Jenko ${ }^{2}$, Boštjan Kocjančič ${ }^{3}$, Drago Dolinar ${ }^{3}$, Urban Brulc ${ }^{1}$ \\ ${ }^{1}$ MD Medicina, Bohoričeva 5, 1000 Ljubljana, Slovenia \\ 2Institute of Metals and Technology, Lepi pot 11, 1000 Ljubljana, Slovenia \\ ${ }^{3}$ University Medical Centre Ljubljana, Department of Orthopaedic Surgery, Zaloška 9,1000 Ljubljana, Slovenia \\ urban.brulc@gmail.com
}

Prejem rokopisa - received: 2017-11-22; sprejem za objavo - accepted for publication: 2018-01-04

doi:10.17222/mit.2017.197

\begin{abstract}
Spinal interbody fusion (spondylodesis) remains a gold standard for the treatment of instability, deformity and degenerative disease of the spine. Over the past 40 years surgical techniques and implant-device (cage) technology for spinal fusion have changed significantly. Design and materials have evolved with one common goal, to develop suitable implants that would address all three major issues of the procedure: stability, restoration of lordosis and osteointegration. Historically, two main materials have been utilized in the creation of cages: titanium (Ti) and polyetheretherketone (PEEK). The focus of spinal surgeons is constantly shifting from one material to another, because of the aggressive, commercial drive from the industry. The choice of optimal spinal interbody fusion device was always a matter of controversy. Therefore, this article aims to provide an overview of the different materials and designs from the biomechanical and also clinical aspect. A systematic review of the literature was made. The inadequate available clinical trials and lack of comparisons between different models have prevented definitive conclusions; therefore, further prospective randomized studies are necessary in the future to define one cage as a mainstay of clinical practice.

Keywords: spondylodesis, cage, titanium, polyetheretherketone
\end{abstract}

Zatrditev hrbteničnega segmenta (spondilodeza) predstavlja zlati standard zdravljenja nestabilnosti, deformacij in degenerativnih bolezni hrbtenice. V zadnjih 40 letih so se kirurška tehnika in umetni medvretenčni vsadki (kletke) občutno spremenili. Oblika in materiali so se razvijali z enim skupnim ciljem, to je odkriti vsadek, ki bi omogočal stabilnost hrbteničnega segmenta, vzdrževanje lordoze ter osteointegracijo. Zgodovinsko gledano sta bila dva najpogosteje uporabljena materiala titan in polietereterketon. Dandanes med hrbteničnimi kirurgi ostaja nesoglasje glede optimalne izbire umetnega medvretenčnega vsadka. Namen tega članka je predstaviti prednosti in slabosti najpogosteje uporabljenih materialov. Na podlagi aktualne strokovne literature je bila opravljena primerjava biomehanskih in kliničnih rezultatov različnih vsadkov. Glede na pomanjkljivost naključnih prospektivnih multicentričnih študij ostaja izbira optimalnega umetnega hrbteničnega vsadka še naprej problematična.

Ključne besede: spondilodeza, umetni medvretenčni vsadek, titan, polietereterketon

\section{INTRODUCTION}

Spinal interbody fusion (spondylodesis) remains a "gold standard" for the treatment of spinal instability, deformity, degenerative disc disease, infection and failed decompressive spinal surgery. ${ }^{1}$ Substantial effort has been made to optimise surgical techniques and even more substantial to develop suitable implants that would address all three major issues of the procedure: stability, restoration of lordosis and osteointegration. The era of interbody fusion began with mesh cages, manly produced from titanium. ${ }^{2}$ This first generation of cages was met with great expectations, but little knowledge of anatomical postulates such as sagittal balance and the importance of segmental lordosis. Results were relatively favourable in the early post-surgical period, with good interbody fusion, but this deteriorated with years. ${ }^{3}$ The beginning of the $21^{\text {st }}$ century brought up the advent of implants made of polyetheretherketone or popular PEEK. Its biomechanical properties were closer to bone then those of the titanium implants. Therefore, the hopes were high, but again short-lived. PEEK implants have indeed improved the possibility of the anatomical restauration of diseased segment, but failed to persuade with its limited osteointegration. ${ }^{4}$ Currently, there is a lack of consensus among spinal surgeons. The focus is constantly shifting from one material to another, because of aggressive, commercial drive from the industry, which develops and promotes new and new products. Consequently, the choice of optimal spinal interbody device has remained a matter of controversy. This article therefore aims to provide an overview of the different materials and designs from biomechanical and also clinical aspect.

\section{TITANIUM CAGES}

The history of spinal interbody fusion devices stems back to the original cage implant developed by Bagby. It was made from a stainless steel and used for the treatment of cervical instability in thoroughbred horses. ${ }^{5}$ Titanium cages were first introduced in 1986 by Harms 


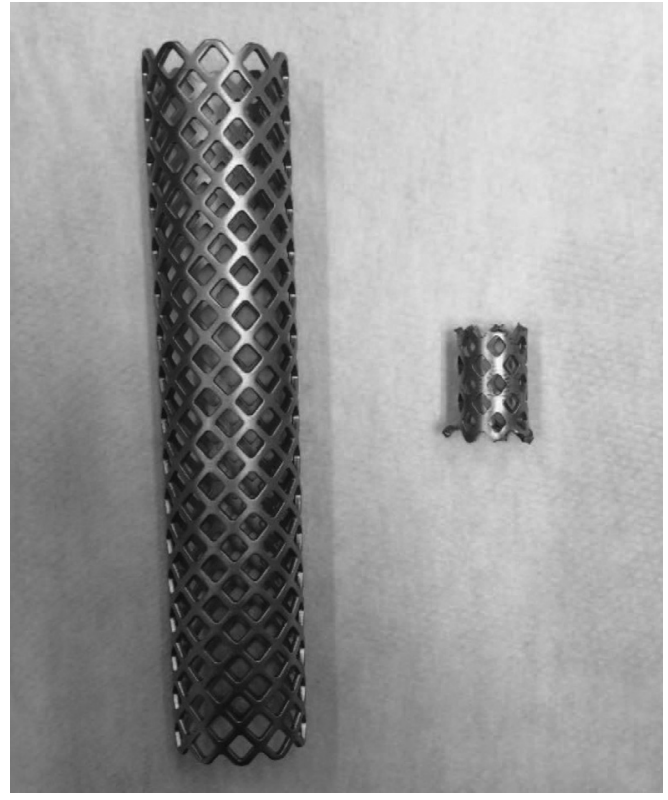

Figure 1: Titanium mesh cage

and Biederman. The design of these cages involved mesh that has been rolled into cylindrical shape and reinforced with rings at each end (Figure 1). They were traditionally filled with autograft (spongiose bone). ${ }^{6}$

Titanium was chosen because of excellent corrosion resistance, low density (approximately $4700 \mathrm{~kg} / \mathrm{m}^{3}$ ) and biocompatibility. Due to its ability to enhance osseointegration the early results of first generation implants were very promising. ${ }^{3,7}$ Biomechanically, Ti-alloy implants demonstrate close approximation with surrounding bone. It was reported that Ti-alloy surfaces with complex micron/submicron scale roughness promote osteoblastic differentiation and foster a specific cellular environment that favors bone formation whereas other materials favours fibrous tissue formation. ${ }^{8,9}$ Clinically this means higher fusion rates, which is the main objective of spondylodesis.

However, the use of titanium and its alloys also poses several issues for interbody fusion. Firstly, there is a mismatch between the elastic modulus of titanium (110 $\mathrm{GPa})$ and that of vertebrae trabecular bone $(2.1 \mathrm{GPa})$ and cortical bone $(2.4 \mathrm{GPa})$. This elastic modulus mismatch results in reduced stress shielding around the implant which can precipitate graft subsidence. The result is kyphotic alignment of fused segment and aggravation of pain. ${ }^{10-12}$ A second major issue with the use of titanium is its high radio-density. Therefore, the accurate assessment of radiographic fusion status after operation is much harder to achieve. ${ }^{7}$

\section{POLYETHERETHERKETONE CAGES}

To address the before-mentioned disadvantages of titanium and titanium alloys, polyetheretherketone (PEEK) cages were developed (1990s, AcroMed). PEEK is a hydrophobic, organic and thermoplastic polymer. ${ }^{13}$
The initial interbody devices constructed of plastic material were either round or hexagonal shape designed as a spacer with a central cavity for bone graft placement.

The hopes were high again because of their biomechanical properties. PEEK is perfectly inert and its modulus of elasticity $(3.5 \mathrm{GPa})$ is similar to that of cortical bone. This may promote even load sharing and stress distribution which can be translate into lower subsidence rates. ${ }^{12,14}$ Some studies have suggested that PEEK materials are relatively resistant to microbial adhesion and hence associated with lower infection rates than their titanium counterparts. ${ }^{15}$ Continuously, its minimal radiographic signature allows optimal evaluation of bony fusion on plain radiographs and computed tomography (Figure 2). There is also no risk of metal allergy. ${ }^{4}$

PEEK implants have indeed improved possibility of anatomical restauration of diseased segment, but its chemical inertness limits an ability to osseointegrate into the surrounding bone environment. ${ }^{14,16}$ The material does not allow protein absorption and cell adhesion, which leads to poor bone contact. With in vitro studies was demonstrated that implants fabricated from PEEK are often encapsulated by fibrous tissue. This can be due to reduced osteoblastic differentiation of progenitor cells and production of an inflammatory environment that favours cell death via apoptosis and necrosis. ${ }^{8,17}$

\section{TITANIUM-POLYETHERETHERKETONE COMPOSITE CAGES}

An ideal cage design would restore healthy alignment and disc height and achieve immediate post-operative stability, high-fusion rates and low complication rates. To combine advantages of both materials, titanium and PEEK, composite fusion devices were developed (Figure 3). It was shown that PEEK implants coated by a

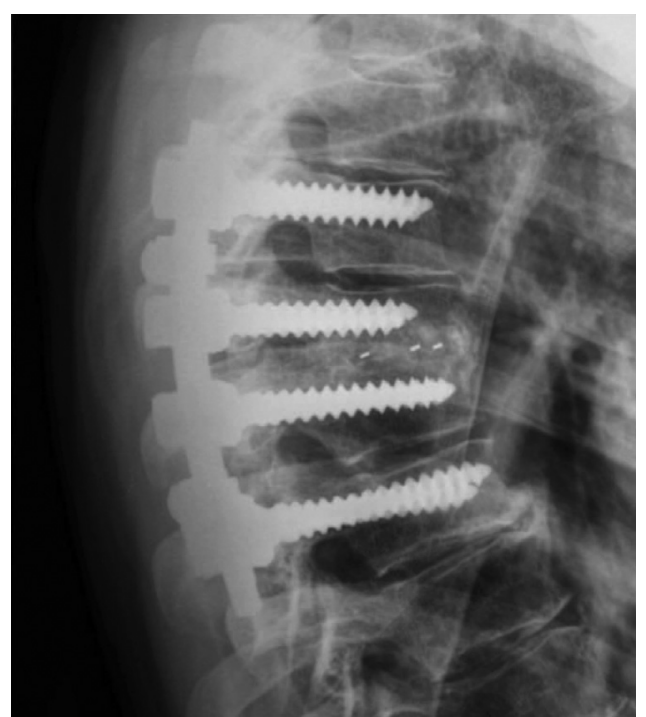

Figure 2: X-ray image of thoracic spine after spondylodesis. An accurate assessment of radiographic fusion status is possible due to the radiolucency of PEEK cage 


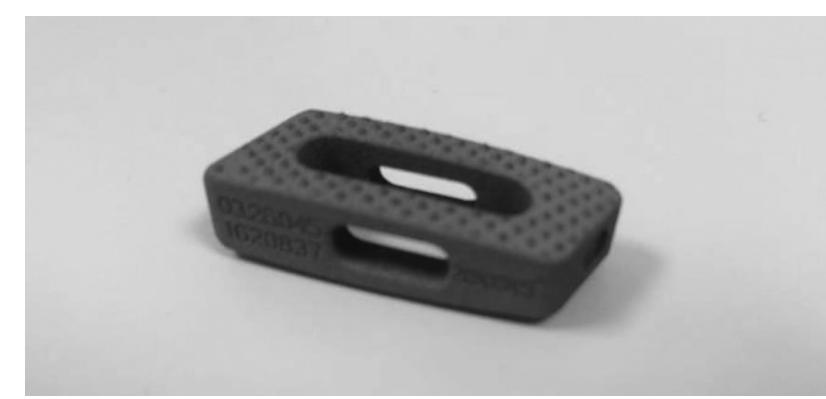

Figure 3: Titanium endplates on a PEEK cage

thin layer of titanium improves bioactivity of material and consequently enhance osseointegration. ${ }^{18}$ Recently, biomechanical and histologic analyses were performed in an ovine lumbar interbody fusion model. Ti-Peek construct demonstrated significant increase in bone on-growth. It was concluded that Ti-Peek inter-body devices could potentially lead to a more robust intevertebral fusion relative to a standard PEEK device (Figure 4). ${ }^{19}$ On the other hand, we have studies which contradict to a good results of composite spacers. Predominant problem may be wear debris and delamination caused by shear loading. With a biomechanical study the impaction process in clinical practice was simulated. It was confirmed that titanium coated implants are susceptible to impaction related wear debris and delamination. ${ }^{20}$

\section{COMPARISON BETWEEN DIFFERENT MATERIALS AND DESIGNS- CLINICAL ASPECT}

Current literature suggests comparable radiographic and clinical outcome of titanium and PEEK devices. No statistical significant difference was found between this two groups in the rate of patient performance. Minimal evidence are present for increased radiographic subsidence with titanium cages, however not statistically important.

R. F. M. R. Kersten et al. ${ }^{21}$ performed a study to assess the clinical aspect of PEEK cages in the treatment of degenerative disc disorders in the cervical spine. Systematic review of all randomized controlled trials and prospective nonrandomized comparative studies was done. The primary outcome variable was clinical performance of patients, and secondary was consisted of radiographic scores. They found minimal evidence for better clinical and radiographic outcome for PEEK cages compared with bone grafts in the cervical spine, but no differences were found between PEEK, titanium, and carbon fibre cages. Another review of the literature was done in June 2017 by S. Seaman et al. ${ }^{22}$ This time titanium and PEEK cages have been evaluated in the cervical and lumbar spine. Six large studies were included in meta-analysis with a total of 410 patients (Ti-228, PEEK-182) and 587 levels (Ti-327, PEEK260). No statistically significant difference was found between groups in the rate of fusion (OR 1.16, 95\% C.I

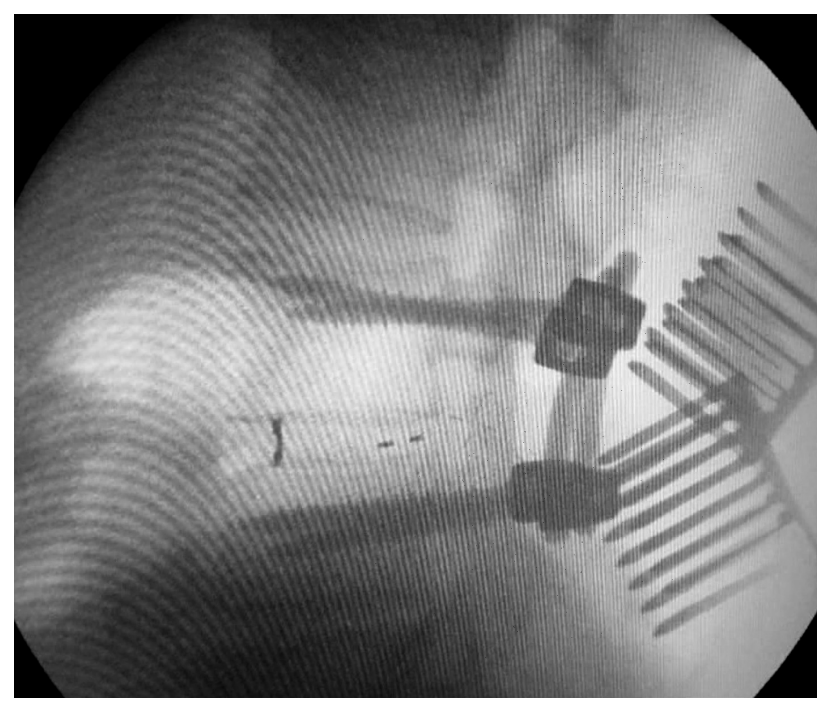

Figure 4: X-ray image of lumbar spine after spondylodesis. Ti-PEEK cages could potentially enhance osteointegration and prevent subsidence

0.59-2.89, $\mathrm{p}=0.686$ ) but there was an increased rate of subsidence with titanium cage.

The last group of cages which stays to be compared are titanium coated PEEK cages. The novelty of this intervention translates into a paucity of clinical trials. Nevertheless, it was possible to find a published study which summarise radiological and clinical outcomes at this early stage. In the meta-analysis combined of seven reports, authors concluded that Ti-PEEK implants are safe and efficacious, exhibiting similar fusion rates and clinical outcomes compared to the current standard PEEK. There is clinical evidence substantiating the improved radiographic fusion of Ti-PEEK, albeit the differences were not significant. ${ }^{23,24}$

\section{CONCLUSION}

The aim of this article was to present the advantages and disadvantages of different spinal interbody fusion devices. On the basis of novel literature, each material was discussed separately and at the end compared to one another. All in all, multiple promising designs are currently available; however, a completely optimal material does not exist. The inadequate available clinical trials and lack of comparisons between different models have prevented definitive conclusions; therefore, further prospective randomized studies are necessary in the future to define one cage as a mainstay for clinical practice.

\section{REFERENCES}

${ }^{1}$ R. J. Mobbs, K. Phan, G. Malham, K. Seex, P. J. Rao, Lumbar interbody fusion: techniques, indications and comparison of interbody fusion options including PLIF, TLIF, MI-TLIF, OLIF/ATP, LLIF and ALIF, J. Spine Surg., 1 (2015), 2-18, doi:10.3978/j.issn.2414469X.2015.10.05 


\section{GORENŠEK et al.: TOWARDS THE OPTIMUM SPINAL FUSION DEVICE}

${ }^{2}$ K. Phan, R. J. Mobbs, Evolution of Design of Interbody Cages for Anterior Lumbar Interbody Fusion, Orthop. Surg., 8 (2016), 270-277, doi:10.1111/os.12259

${ }^{3}$ D. Grob, S. Daehn, A. F. Mannion, Titanium mesh cages (TMC) in spine surgery, Eur. Spine J., 14 (2005), 211-221, doi:10.1007/ s00586-004-0748-7

${ }^{4}$ J. J. P. Schimmel, M. S. Poeschmann, P. P. Horsting, D. H. W Schönfeld, J. van Limbeek, P. W. Pavlov, PEEK Cages in Lumbar Fusion: Mid-term Clinical Outcome and Radiological Fusion, J. Spinal Disord. Tech., 29 (2012), 252-258, doi:10.1097/BSD. 0b013e31826eaf74

${ }^{5}$ R. M. DeBowes, B. D. Grant, G. W. Bagby, A. M. Gallina, R. D. Sande, M. H. Ratzlaff, Cervical vertebral interbody fusion in the horse: a comparative study of bovine xenografts and autografts supported by stainless steel baskets, Am. J. Vet. Res., 45 (1984), 191-199

${ }^{6}$ T. A. Zdeblick, F. M. Phillips, Interbody cage devices, Spine, 28 (2003), 2-7, doi:10.1097/01.BRS.0000076841.93570.78

${ }^{7}$ P. J. Rao, M. H. Pelletier, W. R. Walsh, R. J. Mobbs, Spine interbody implants: material selection and modification, functionalization and bioactivation of surfaces to improve osseointegration, Orthop. Surg., 6 (2014), 81-89, doi:10.1111/os.12098

${ }^{8}$ R. Olivares-Navarrete, S. L. Hyzy, P. J. S. Losar, J. M. Schneider, Z. Schwartz, B. D. Boyan, Implant Materials Generate Different Periimplant Inflammatory Factors: Poly-ether-ether-ketone Promotes Fibrosis and Microtextured Titanium Promotes Osteogenic Factors, Spine, 40 (2015), 399-404, doi:10.1097/BRS.0000000000000778

${ }^{9}$ R. A. Gittens, R. Olivares-Navarrete, Z. Schwartz, B. D. Boyan, Implant Osseointegration and the Role of Microroughness and Nanostructures: Lessons for Spine Implants, Acta Biomater., 10 (2014), 3363-3371, doi:10.1016/j.actbio.2014.03.037

${ }^{10}$ B. S. Bal, M. N. Rahaman, Orthopedic applications of silicon nitride ceramics, Acta Biomater., 8 (2012), 2889-2898, doi:10.1016/ j.actbio.2012.04.031

${ }^{11}$ C. C. Niu, J. C. Liao, W. J. Chen, L. H. Chen, Outcomes of interbody fusion cages used in 1 and 2-levels anterior cervical discectomy and fusion: titanium cages versus polyetheretherketone (PEEK) cages, J. Spinal Disord. Tech., 23 (2010), 310-316, doi:10.1097/BSD. 0b013e3181af3a84

${ }^{12}$ S. M. Kurtz, J. N. Devine, PEEK Biomaterials in Trauma, Orthopedic, and Spinal Implants, Biomaterials, 28 (2007), 4845-4869, doi:10.1016/j.biomaterials.2007.07.013

${ }^{13}$ I. V. Panaayotov, V. Orti, F. Cuisinier, J. Yachouh, Polyetheretherketone (PEEK) for medical applications, J. Mater. Sci. Mater. Med., 27 (2016), 118, doi:10.1007/s10856-016-5731-4

${ }^{14}$ M. H. Pelletier, N. Cordaro, V. M. Punjabi, M. Waites, A. Lau, W. R. Walsh, PEEK Versus Ti Interbody Fusion Devices: Resultant Fusion, Bone Apposition, Initial and 26-Week Biomechanics, Clin. Spine Surg., 29 (2016), 208-214, doi:10.1097/BSD.0b013e31826851a4
${ }^{15}$ H. Kakinuma, K. Ishii, H. Ishihama, M. Honda, Y. Toyama, M. Matsumoto, Antibacterial polyetheretherketone implants immobilized with silver ions based on chelate-bonding ability of inositol phosphate: processing, material characterization, cytotoxicity, and antibacterial properties, J. Biomed. Mater. Res., 103 (2015), 57-64, doi:10.1002/jbm.a.35157

${ }^{16}$ O. Nemoto, T. Asazuma, Y. Yato, H. Imabayashi, H. Yasuoka, A. Fujikawa. Comparison of fusion rates following transforaminal lumbar interbody fusion using polyetheretherketone cages or titanium cages with transpedicular instrumentation, Eur. Spine J., 23 (2014), 2150-2155, doi:10.1007/s00586-014-3466-9

${ }^{17}$ R. Olivares-Navarrete, R. A. Gittens, J. M. Schneider, S. L. Hyzy, D. A. Haithcock, Ullrich PF, Osteoblasts exhibit a more differentiated phenotype and increased bone morphogenetic protein production on titanium alloy substrates than on poly-ether-ether-ketone, Spine J., 12 (2012), 265-272, doi:10.1016/j.spinee.2012.02.002

${ }^{18}$ W. R. Walsh, N. Bertollo, C. Christou, D. Schaffner, R. J. Mobbs Plasma-sprayed titanium coating to polyetheretherketone improves the bone-implant interface, Spine J., 15 (2015), 1041-1049, doi:10.1016/j.spinee.2014.12.018

${ }^{19}$ K. C. McGilvray, E. I. Waldorff, J. Easley, H. B. Seim, N. Zhang, R. J. Linovitz, Evaluation of a polyetheretherketone (PEEK) titanium composite interbody spacer in an ovine lumbar interbody fusion model: biomechanical, microcomputed tomographic, and histologic analyses, Spine J., 17 (2017), 1907-1916, doi:10.1016/j.spinee. 2017.06.034

${ }^{20}$ A. Kienle, N. Graf , Does impaction of titanium-coated interbody fusion cages into the disc space cause wear debris or delamination?, Spine J., 16 (2016), 235-242, doi:10.1016/j.spinee.2015.09.038

${ }^{21}$ R. F. M. R. Kersten, S. M. van Gaalen, A. de Gast, F. C. Öner, Polyetheretherketone (PEEK) cages in cervical applications: a systematic review, Spine J., 15 (2015), 1446-1460, doi:10.1016/j.spinee. 2013.08.030

${ }^{22}$ S. Seaman, P. Kerezoudis, M. Bydon, J. C. Torner, P. W. Hitchon, Titanium vs. polyetheretherketone (PEEK) interbody fusion: Metaanalysis and review of the literature, J. Clin. Neurosci., 44 (2017), 23-29, doi:10.1016/j.jocn.2017.06.062

${ }^{23}$ E. Chong, R. J. Mobbs, M. H. Pelletier, W. R. Walsh, Titanium/ Polyetheretherketone Cages for Cervical Arthrodesis with Degenerative and Traumatic Pathologies: Early Clinical Outcomes and Fusion Rates, Orthop. Surg., 8 (2016), 19-26, doi:10.1111/os.12221

${ }^{24}$ Y. Assem, R. J. Mobbs, M. H. Pelletier, K. Phan, W. R. Walsh, Radiological and clinical outcomes of novel Ti/PEEK combined spinal fusion cages: a systematic review and preclinical evaluation, Eur. Spine J., 26 (2017), 593-605, doi:10.1007/s00586-015-4353-8 